\title{
On the Modern Teacher's Job Specification: Results of a Representative Survey of School Directors
}

\author{
Gediminas Merkys ${ }^{1}$, Nijolè Čiučiulkiené ${ }^{2}$, Daiva Bubeliené $\dot{B}^{3}$
}

1 Vytautas Magnus University, Academy of Education, T. Ševčenkos g. 31, LT-03111 Vilnius, Lithuania, gediminas.merkys@vdu.lt

2 Vytautas Magnus University, Academy of Education, T. Ševčenkos g. 31, LT-03111 Vilnius, Lithuania, nijole.ciuciulkiene@vdu.lt

3 Kaunas University of Applied Sciences, Faculty of Medicine, Pramonės pr. 20, LT-50468 Kaunas, Lithuania, daiva.bubeliene@go.kauko.lt

Annotation. The article reveals the importance of non-cognitive personality characteristics (NPC) for the successful professional activities of teachers. In the modern teacher training system, the role of the NPC is not estimated enough, the modern models of school and university socialization do not contribute to the successful formation of the NPC. The theoretical discussion of this research paper is based on the results of the mass survey $(\mathrm{N}=929)$ of school principals' attitudes on NPC. The findings show that school leaders recognize the importance of the NPC for professional success.

Keywords: non-cognitive personality characteristics, school and university socialization, teacher training; survey of school principals, cognitive reductionism.

\section{Introduction}

The modern labor organization, like the entire labor market, is very dynamic, demonstrating an inclination to a rapid, sometimes very significant pace of change. Jobs and work functions are becoming more complex, the requirements for applicants for any position are constantly increasing. This tendency is primarily related to the specialists with a university education, including teachers. The sensible designation and constant updating of the requirements for applicants for the position of a specialist is a reasonable 
challenge, both for science and for the practice of human resource management (HRM). In such branches of knowledge as labor psychology and HRM, the above mentioned problem and the way to solve it are defined by specific scientific terms "Job Description" (Morgeson, Brannick et. al., 2019) and "Job Specification" (Ellington, Brannick, Levine, 2015). In the Russian speaking countries and the corresponding cultural space, the scientific concept of the professiogram has been deeply rooted and has long been established (Еремеев, 2018; Иванова, 2013).

The analytical and modeling function of the mentioned concepts lies in the fact that they allow the development of complex taxonomies in the process of solving the perennial problem of Staff Management - the right person / employee at the right workplace. All the same, the mentioned concepts regarding the training of young teachers or the professional development of already employed teachers, in our opinion, are little exploited both: in empirical research and in scientific literature. A possible reason for this is the obvious pragmatic orientation of the concept, the absence of an element of scientific novelty and theoretical intrigue in its semantics.

The concepts of "competence" and "emotional intelligence" EQ are considered to be fashionable in contemporary empirical and theoretical research. There is a myriad of publications about the "competence" not only of teachers, but the representatives of many other professions as well. Owing to excessive exploitation, the concept of competence turns into an ideologeme and is partly devalued. The epistemological limitation and riskiness of the concept of competence are revealed by the fact that it sometimes quite arbitrarily moves away from personality psychology and differential psychology. Meanwhile, from the point of view of the paradigm of modern behavioral sciences, it is impossible to refute the postulate that the success of any type of human activity is a function of a certain set of internal personality dispositions.

The concept of EQ, in its turn, has become (and remains in the future) innovative and productive in the sense that it significantly drew attention to the superimportance of some non-cognitive structures and personality functions in the process of ensuring the success of a person as a whole, including all the main spheres of his/her life, for example, career, family life, and partnership, harmonious interior world. Despite the epistemological advantages, though the concept of EQ still does not touch upon a whole layer of personal behavioral characteristics that do not belong to the cognitive sphere, it still plays a key role in the processes of ensuring the success of the human activity, including work and professional activity. First of all, it is will, activity, initiative. An employee can have high EQ and IQ and at the same time be weak-willed, lacking of initiative. Furthermore, a certain limitation of EQ lies in the fact that this construct is completely cut off from the set/profile of specific ideological and moral values, although the latter is extremely important for the teaching profession. Figuratively speaking, members of a close-knit group of scammers, especially the leader of the group, can also have high EQs. 
The above presented considerations about some of the dysfunctions of the concepts of "competence" and "EQ" lead to the idea of the appropriateness of such a working concept as non-cognitive personality characteristics (NPC). It is well known that the entire internal structure of the personality is mainly divided into cognitive and non-cognitive spheres. In our opinion, at the theoretical level, it seems appropriate to interfere with NPC and such, in the process of teacher training, deprived of attention to concepts such as "Job Description" and "Job Specification". In its own turn, the conceptual education of NPC in research both on HRM and on the professionalization of teachers is not a fashionable trend. The use of this term as the core of the working concept of empirical research is extremely rare. On the other hand, there are considerable, not yet properly used, heuristic possibilities of such a working term as NPC (Mayr, 2010; 2014). Thus, the theoretical and semantic connotations of the mentioned concepts "Job Description", "Job Specification", and NPC constitute the conceptual basis of this research.

A lot of both theoretical and empirical studies have been carried out in the last decade (Mayr, 2010; 2014; Cramer \& Binder, 2015; Neubauer, et. al., 2017; Brown, 2017; Chuc \& Herrera, 2017; Klassen et. al., 2018; Feng, 2018; Galton \& Moon, 2018; Pérez-Nebra et. al., $2020)$ in the indicated conceptual context. Thus, this article fits into discourse on the broader topic of "teacher training in the 21st century". The scientific problem investigated in this research paper can be identified by specific research questions.

- What professional and personal qualities should employ teachers, graduates of teacher training colleges and universities who have received a modern education have?

- What kind of young teachers is a modern school waiting for?

- What professional requirements are school directors who are also employers setting for applicants?.

- To what extent do school principals realize or do not realize the critical importance of NPC in the process of professionalizing a modern teacher?

The research was devoted to finding the solutions to the questions posed. The results of the survey are presented in this article. Still, the questions raised to cover the broadest field of scientific discourse and cannot be resolved within a single research paper.

\section{Research methodology, sample and survey tool}

In the fall of 2019, a database of 929 answers was formed through an electronic survey of directors of general education schools. This is $93 \%$ of the corresponding population in the Republic of Lithuania as a whole. It seems possible to speak almost of a general survey of the target population. The sample naturally presents schools of all 60 regional self-government entities of the country. 
It is common knowledge that the leaders of organizations, both private and public, represent a very unique target group. It is sometimes extremely difficult to get them as respondents to social surveys. The almost universal involvement of school leaders in the online survey project, in our opinion, was due to a number of circumstances. First of all, this is the pragmatism and importance of the survey topic for the school and society. The question of the actual need of a particular school in the teaching staff at the current moment was investigated as the main one. Presumably, the extreme brevity of the questionnaire also played a positive role. The impressive refund quota was paid for by the ascetic set of variables.

The paper presents only the analysis of the results on a single "open" question, which had the following formulation: "A school principal is an employer of novice teachers. What kind of teacher are you and your school looking forward to? What instructions, recommendations, and advice would you like to formulate for the university and the teacher training university as an employer? The latter question is extremely relevant for the university, which was the customer of the survey. The generalized answers to this question are important for the targeted improvement of the content of teacher training and the marketing of the university.

In the presented formulation of an open question, not a single scientific concept, such as "competence", EQ, etc., is used. The formulation is based solely on the concepts of the everyday level and "consciousness of everyday life". This is a targeted research tactic by means of which the imposition of a specific orientation and content of answers to respondents, their a priori binding to a certain theoretical concept is prevented. According to the phenomenological approach and the normative principle of openness, it was supposed to spur the flow of ideas about the "modern good teacher", which follow from the corresponding individual subjective theory (Lamnek) that has already developed in each school principal. The mission of the researcher is that these subjective and authentic representations are comprehensively interpreted.

For the survey, the professional online survey platform „Survey Monkey“ was used. The survey was anonymous, as the respondents were indicated only by the name of the region / local government and the type of school.

\section{Data processing and research findings}

The MAXQDA computer program was used to process the array of primary responses. Analysis and data processing was carried out using the method of quantitative manifested content analysis (Lamnek, 2010; Schreier, 2014; Mayring, 2015). In the syntax of the array of answers, indivisible semantic units were found and fixed. Further, similar or single-meaning units were combined into generalized categories. After that, it seemed possible to calculate the absolute and relative frequencies of semantic units and make 
a frequency rating of the selected categories. This was followed by the interpretation of the revealed rating.

The corresponding method of a free answer to an "open" type question, despite its apparent simplicity, has a significant heuristic advantage. In this case, no theoretical hypothetical ideas of the researchers are imposed on the respondents. A certain topic, specific content, and all kinds of semantic accents of the answer are generated exclusively by the respondents themselves. The generalized answers represent a reflection of the collective consciousness of the most important professional group in terms of school teachers' training - school leaders and employers. Although research as a whole belongs to the category of quantitative research, nevertheless, as regards the primary generation and removal of answers, we are talking about the implementation of the principles of qualitative research. First of all, we are talking about the principle of openness in qualitative research (Hollway \& Jefferson, 2000; Krippendorf, 2004; Lamnek, 2010; Schreier, 2014; Mayring, 2015). After all, the previously theoretically set and in the course of the research no longer changing structure of indicators closes the quantitative research in itself. In this case, the identification of new, previously unknown aspects and nuances of the phenomenon under study becomes very unlikely. The method of open-ended questions of this methodological "ailment" is completely devoid of, which is its indisputable advantage.

30 generalized meaningful categories were identified. Fig. 1. demonstrates the ranking of categories by the relative frequency of their mention. In a stronger tone, the figure denotes personal properties and professional characteristics of a non-cognitive nature. 19 categories (out of the 30), reflect parameters of a non-cognitive nature, which is a relative value of 0.633 . At the very top of the ranking, there appears the "intrinsic motivation and vocation" of the teacher. It is trivial to assert that the mentioned personality characteristics are not directly connected with the basic cognitive constructs - IQ, thinking, mnemonic processes.

\section{Interpretation of the research findings and scientific discussion}

What, in our opinion, is the main result of the survey, which is worth a thorough understanding? The study revealed the relative importance from the point of view of employers of such professional characteristics of a successful teacher, which fall under the collective concept of "non-cognitive personality characteristics". First of all, these are "internal motivation and vocation," "love for children," "self-improvement," "initiative," etc. Speaking in ordinary non-academic language, it is quite clear that there is a social order and the employer's expectations that a job applicant who wants to be a teacher had personal maturity. 


\section{Figure 1}

Frequency Rating of Generalized Categories About the Desired Professional Properties of a Modern Teacher

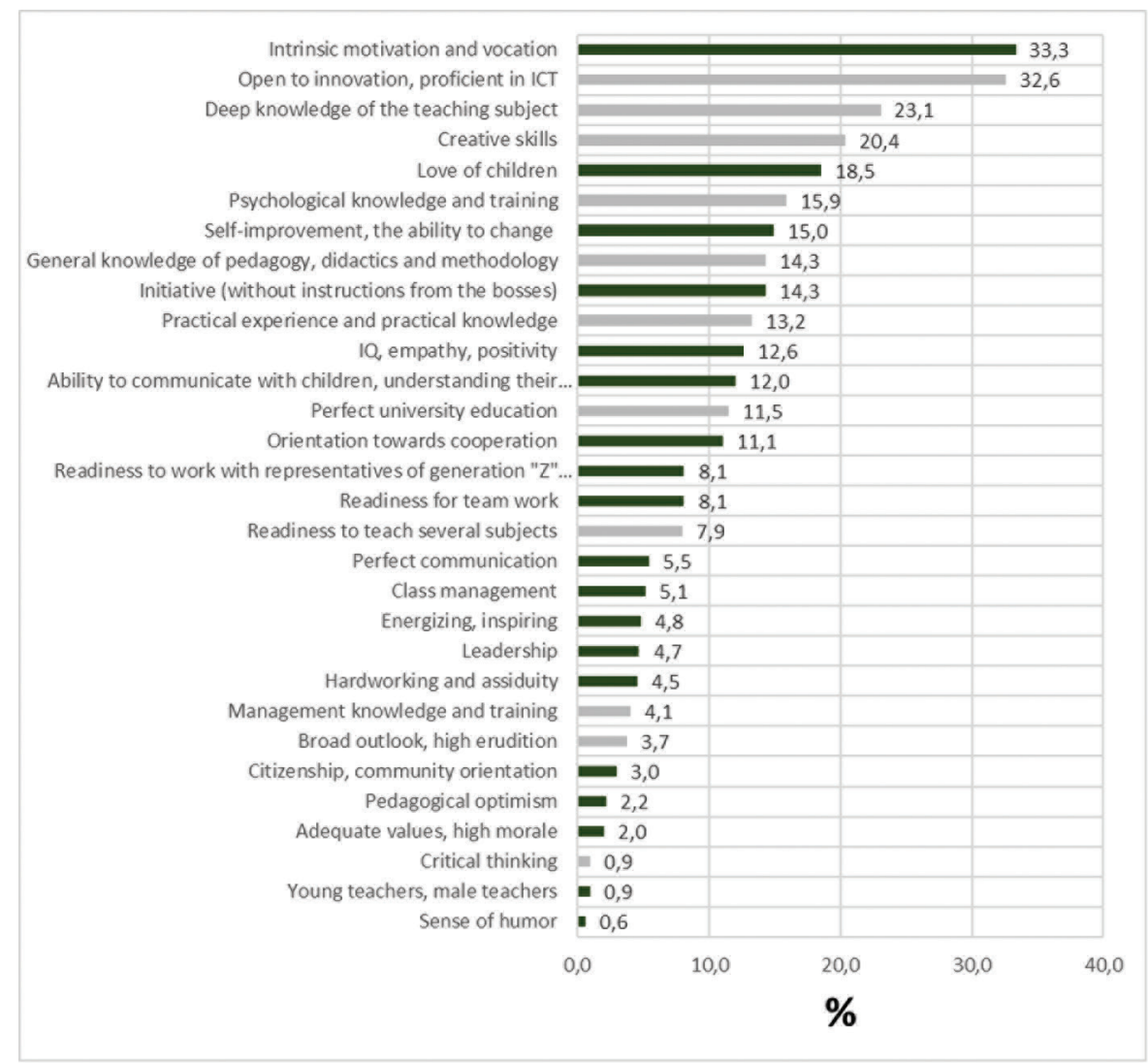

Note. Answers of school principals, $\mathrm{N}=929$. NPCs in the figure are marked with a stronger tone.

The expectation is trivial, because, indeed, not everyone can be a successful teacher. The professional success of a teacher is largely determined by his/her personal maturity and fully developed NPC. In particular, it is desirable that any employee should have high emotional intelligence (EQ) (Butler \& Chinavsky, 2006; Antinienè, 2015), since this has a positive effect on the social climate, on the coherence of teamwork, and, through this, on the final results of the labor organization as a whole. If a programmer, financial analyst or archivist has developed EQ only at an intermediate level, then the corresponding circumstance does not mean professional unsuitability. In the case of a teacher's noble and most difficult mission, his/her underdeveloped EQ is likely to turn into professional unsuitability. Even theoretically, it is difficult to imagine a professionally successful teacher with poorly developed NPC. 
The above mentioned facts do not in any way diminish the importance of the outstanding cognitive abilities of a successful teacher, like any other specialist with a higher education. Nevertheless, to some extent, the question is trivial, since without the corresponding abilities of at least an intermediate level, entering a university and its successful completion is very unlikely.

According to our data, not only school principals, but also employers in the private business sector complain about the lack of personal maturity of some university graduates (Goddard \& Goddard, 2006; Liston et al., 2006; Venclauskienė, 2016). Employers too often have a bad experience and are disappointed with the first employment of a "freshly baked" university graduate. Employers, heads of private recruitment agencies, as well as representatives of the state employment and employment service pay attention to the egocentrism and even social infantilism of a large part of young applicants, not to mention the lack of such qualities as responsibility, engagement, involvement, and commitment (Halbesleben, 2010; Липатов, 2015; Масилова \& Бурцева, 2016; Кравченко, 2018; Arens \& Morin, 2016). In particular, from interviews with employers and heads of recruitment agencies, it is known that graduates sometimes come to interviews with employers unprepared, simply not taking an interest in either the sector or the organization, while presenting unrealistic, clearly overestimated salary demands, without looking back at the real economic productivity of the novice worker. In a short time, many labor organizations change or quit their first job just because another employer offered a company car and a smartphone of a more prestigious brand. On the other hand, we almost never heard complaints from the mentioned group of informants that graduates did not have proper theoretical training, do not know a foreign language enough, do not understand computer technologies, do not know how to independently find and analyze information.

The main problem is that full-fledged NPC can hardly be successfully formed only at a student's desk. Education in a university is, first of all, an intensive activity of a cognitive nature, and motivation, will, emotional stability, responsibility, ideological attitudes, and values are contextual prerequisites for academic activity proper. It should be emphasized that the foundations of NPC are formed in early childhood and in the process of school socialization. The key prerequisites for the successful formation of NPC are the diversity of social roles, the meeting of a child or adolescent with the challenges and problems of real life. Here, high-quality extracurricular activities are extremely important, as well as a variety of non-academic forms of social activity of students, including volunteering, participation in the activities of non-governmental organizations. High-quality (real, non-imitated) educational practice of students is of exceptional importance.

A young person must bring with him/her to the university certain socially valuable personal and behavioral dispositions, the totality of which has already been formed at the earlier stages of socialization. It is a big mistake to hope that the "ontogenetic breakthrough" in the development of NPC will take place at the university desk. The mentioned problem has a transcultural nature and is relevant for different systems of 
higher education. In modern high school didactics, it is sometimes successfully solved through the didactic system Service Learning (Kerins, 2016; Caspersz \& Olaru, 2017; Huda \& Jasmi, et al., 2018). According to the above system, students in the good sense of the word are literally expelled into the real life of labor organizations, public and state institutions. They are obliged to independently find a reason and an object for applying the studied theoretical knowledge to solve real problems.

Nevertheless, the established modern typical models of the so-called "successful" school and university socialization are, in our opinion, partly cognitively reduced, partly suffering from academic perfectionism and fetishisation of formal indicators of academic performance (tutoring, USE). Six hours at school, at least 2 hours at the tutor, then homework, plus the time which is taken for getting to the tutor and returning home. Such a situation opens quite a tricky situation: a schoolchild has at least 10-12 working hours per day. To a certain extent, we are talking about a model of deprived socialization, since there is not enough time physically for a variety of activities and for testing various social roles that are most important for a child/adolescent. Scoliosis, myopia, obesity, nervous disorders, bad habits, loss of all (and primarily social) activity, as well as poorly developed NPC in young men/girls are natural consequences of academic perfectionism.

\section{Conclusions}

Reliable selection for the teaching profession should not be limited to a single one-time testing of cognitive-academic abilities. In parallel, a system of early professional identification and selection is necessary, which is stretched over time, based on the biographical method, expert assessments, the so-called idiographic (qualitative) methodology. The result of the corresponding diagnosis and the decision on the expected professional suitability should be objectively reflected in a well-formed "portfolio" of competencies and achievements.

At the same time, the belonging of the future teacher to the elite, to $5-7 \%$ of the most intellectually gifted applicants, is highly desirable, but not obligatory. It will not be reprehensible if the majority of applicants who reach the 55-75 percentile rank enter the pedagogical university, which can be interpreted as a level above the average. It is much more important that the applicant, as far as it is real for a young man, already possesses certain basic NPC, so important for a professionally successful teacher. This refers to empathy, EQ, social responsibility, values, and attitudes adequate to the teacher's mission, etc.

In light of the problem of the importance of NPC for the successful professional activity of a teacher, the model of parallel training of young teachers is the most acceptable. The corresponding model allows for the possibility of early, prolonged, professional selection based on expert and biographical methods. In addition, there is enough time at the disposal of the student to seriously go through step-by-step school practices: class 
leadership, teacher assistant, subject teacher, and also have a natural school base for their own student pedagogical experiences and experiments. An alternative-sequential model assumes that the future teacher first receives a bachelor's degree in the subject and only then in a year additionally collects credits from the psychological and pedagogical block. From the point of view of the problem of the successful formation of the NPC of future teachers, it is the parallel model of teacher training that is more preferable.

The era has passed when a profession and occupation was chosen once and for the rest of one's life. It seems very tempting when a personally and professionally mature person comes to school as a teacher, whose career was not previously directly connected with school. Such a personality can enrich the school community with his/her extraordinary experience, be very interesting for students. The most important thing is that the person entering the position of a teacher and accepting the corresponding noble professional mission has developed non-cognitive personal formations.

The main message of the study and this report is to draw attention to the fundamental importance of NPC for the successful professional activity of a teacher. In the future, it seems relevant to use the proposed concept more boldly and more often in research on university training and professionalization of teachers. The very understanding of the heuristic significance of NPC, in our opinion, gives impetus to the improvement of the paradigm and, accordingly, the very practice of teacher training, which sometimes still remains cognitively reduced.

\section{References}

Antiniene, D. (2015). Emocinis intelektas: Lietuvos jaunimo tyrimas. Mokslo monografija. Kaunas: Technologija.

Arens, A. K., \& Morin, A. J. S. (2016). Relations between teachers' emotional exhaustion and students' educational outcomes. Journal of Educational Psychology, 1, 1-14.

Brown, T. (2017). Teacher education in England: A critical interrogation of school-led training. London, NewYour: Routledge.

Butler, C. J., \& Chinavsky, P. S. (2006). Emotional intelligence and leadership behavior in construction executives. Journal of Management in Engineering, 22(3), 119-125.

Caspersz, D., \& Olaru, D. (2017). The value of service-learning: the student perspective. Studies in Higher Education, 42(4), 685-700.

Chuc, R. E., \& Herrera, P. C. (2017). Upper secondary teachers training and its effect in teaching practice. International Journal of Innovation and Research in Educational Sciences. 4(2), 2349-5219.

Cramer, C., \& Binder, K. (2015). Zusammenhänge von Persönlichkeitsmerkmalen und Beanspruchungserleben im Lehramt. Ein internationales systematisches Review. [Relationships between personality traits and stress experience in teaching. An international systematic review] Zeitschrift für Erziehungswissenschaft, 18(1), 101-123. 
Ellington, J. K., Brannick, M. T., \& Levine, E. L. (2015). Job specification. Wiley encyclopedia of management,1-2. https://doi.org/10.1002/9781118785317.weom050137

Feng, L. (2018). The role of teacher training in beginning teachers' Self-efficacy, job satisfaction, and turnover motivation: Findings from the 2011-2012 schools and staffing survey. [Doctoral dissertation, Texas A \& M University]. http://hdl .handle .net /1969 .1 /173714

Galton, M., \& Moon, B. (Eds.). (2018). Handbook of teacher training in Europe (1994): Issues and trends. London, NewYour: Routledge.

Goddard, R., \& Goddard, M. (2006). Beginning teacher burnout in Queensland schools: associations with serious intentions to leave. Australian Educational Researcher, 33, 61-75. https://doi.org/10.1007/BF03216834

Halbesleben, J. (2010). A meta-analysis of work engagement: relationships with burnout, demands, resources, and consequences. In A. B. Bakker \& M. P. Leiter (Eds.), Work Engagement: a Handbook of Essential Theory and Research (pp.102-117). New York: Psychology Press.

Hollway, W., \& Jefferson, T. (2000). Doing qualitative research differently: free association, narrative and the interview method. London: Sage.

Huda, M., Jasmi, K. A., Alas, Y., Qodriah, S. L., Dacholfany, M. I., Jamsari, E. A. (2018). Empowering civic responsibility: Insights from service learning. Engaged Scholarship and Civic Responsibility in Higher Education. IGI Global, 144-165.

Kerins, A. T. (2016). An adventure in service-learning: Developing knowledge, values and responsibility. London, NewYour: Routledge.

Klassen, R. M., Durksen, T. L., Al Hashmi, W., Kim, L. E., Longden, K., Metsäpelto, R. L., Poikkeus, A. M., \& Györi, J. G. (2018). National context and teacher characteristics: Exploring the critical non-cognitive attributes of novice teachers in four countries. Teaching and Teacher Education, 72, 64-74. https://doi.org/10.1016/j.tate.2018.03.001

Krippendorf, K. (2004). Content analysis. An introduction to its methodology. Newbury Park, California: Sage.

Lamnek, S. (2010). Qualitative sozialforschung. 5. [Qualitative social research]. Weinheim: Beltz. Liston, D., Whitcomb, J., Borko, H. (2006). Too little or too much: Teacher preparation and the first years of teaching. Journal of Teacher Education, 57(4), 351-358.

Mayr, J. (2010). Selektieren und/oder qualifizieren? Empirische Befunde zu guten Lehrpersonen. In J. Abel \& G. Faust (Hrsg.), Wirkt Lehrerbildung? Antworten aus der empirischen Forschung, 73-89. [Select and / or qualify? Empirical findings on good teachers. In J. Abel \& G. Faust (Eds.), Does teacher training work? Answers from empirical research], 73-89. Münster: Waxmann. Mayr, J. (2014). Der Persönlichkeitsansatz in der Forschung zum Lehrerberuf. In E. Terhart, H. Bennewitz \& M. Rothland (Hrsg.), Handbuch der Forschung zum Lehrerberuf, 2, 189-215. [The personality approach in research on the teaching profession. In E. Terhart, H. Bennewitz \& M. Rothland (Eds.), Handbuch der Forschung zum Lehrerberuf]. Münster: Waxmann.

Mayring P. (2015) Qualitative content analysis: Theoretical background and procedures. In: Bikner-Ahsbahs A., Knipping C., Presmeg N. (Eds) Approaches to qualitative research in 
mathematics education. advances in mathematics education (pp. 365-380). Dordrecht: Springer https://doi.org/10.1007/978-94-017-9181-6_13

Morgeson, F. P., Brannick, M. T., \& Levine, E. L. (2019). Job and work analysis: Methods, research, and applications for human resource management. London: Sage Publications.

Neubauer, A. C., Koschmieder, C., Krammer, G., Mayr, J., Müller, F. H., Pflanzl, B., Pretsch, J., \& Schaupp, H. (2017). TESAT - Ein neues Verfahren zur Eignungsfeststellung und Bewerberauswahl für das Lehramtsstudium: Kontext, Konzept und erste Befunde. [TESAT - A new procedure for determining aptitude and selection of applicants for the teacher training course: context, concept and initial findings]. Journal für LehrerInnenbildung, 7, 5-21.

Pérez-Nebra, A. R., Queiroga, F., \& Oliveira, T. A. (2020). Presenteeism of class teachers: Wellbeing as a critical psychological state in the mediation of job characteristics. Revista de Administração Mackenzie, 21(1), 1-26. doi:10.1590/1678-6971/eRAMD200123.

Schreier, M. (2014). Ways of doing qualitative content analysis: disentangling terms and terminologies. In Forum Qualitative Sozialforschung/Forum: Qualitative Social Research, 15(1). https://www.qualitative-research.net/index.php/fqs/article/view/2043/3636

Venclauskienė, L. (2016). Homo sovieticus: pilko ir pliko žmogaus portreto bruožai laisvejjančios Lietuvos spaudoje. Darbai ir dienos, 65, 143-162.

Еремеев, С. Г. (2018). Профессиограмма и ее значение в образовательном процессе. В сборнике: Актуальные проблемы борьбы с преступностью: вопросы теории и практики. Материалы ХХІ международной научно-практической конференции: в 2-х частях. Сибирский юридический институт Министерства внутренних дел Российской Федерации; ред. Н.Н. Цуканов. [Professiogram and its significance in the educational process. In the collection: Actual problems of combating crime: questions of theory and practice. Materials of the XXI International Scientific and Practical Conference: in 2 parts. Siberian Law Institute of the Ministry of Internal Affairs of the Russian Federation; ed. N. N. Tsukanov], 2, 201-204.

Иванова, А. В. (2013). Профессиограмма как эталонная модель специалиста. Актуальные вопросы современной педагогики: материалы III Междунар. науч. конф. Уфа, [Professiogram as a reference model of a specialist. Actual problems of modern pedagogy: materials of the III Intern. scientific. conf. Ufa], 154-155.

Кравченко, Е. М. (2018). The role of leadership in the relationship between collective organizational efficacy and collective work engagement. Психология. Журнал Высшей школь экономики, 15(3), 590-605.

Липатов, С. А. (2015). „Вовлеченность работника в организацию“ или „увлеченность работой“: соотношение понятий. [Employee involvement in the organization "or" work enthusiasm : the relationship of concepts]. Организационная психология, 5(1), 104-110.

Масилова, М. Г., Бурцева, Ю. В. (2016). Вовлеченность персонала как характеристика организационной культуры. [Personnel involvement as a characteristic of organizational culture]. Территория новых возможностей. Вестник Владивостокского государственного университета экономики и сервиса, 3(34), 137-145. 


\title{
Šiuolaikinio mokytojo profesinio tinkamumo vaizdinys: mokyklų vadovų reprezentatyvios apklausos rezultatai
}

\author{
Gediminas Merkys ${ }^{1}$, Nijolè Čiučiulkiené2 ${ }^{2}$ Daiva Bubeliené $\dot{~}^{3}$ \\ Vytauto Didžiojo universitetas, Švietimo akademija, T. Ševčenkos g. 31, 03111 Vilnius, gediminas.merkys@vdu.lt \\ Vytauto Didžiojo universitetas, Švietimo akademija, T. Ševčenkos g. 31, 03111 Vilnius, nijole.ciuciulkiene@vdu.lt \\ Kauno kolegija, Medicinos fakultetas, Pramonès pr. 20, 50468, Kaunas, daiva.bubeliene@go.kauko.lt
}

\section{Santrauka}

Straipsniu siekiama atkreipti dėmesị i nekognityvinių asmenybės savybių išskirtinę svarbą sèkmingai mokytoju profesinei veiklai. Atkreipiamas dėmesys į dvi aplinkybes. Šiuolaikinejje specialistų rengimo sistemoje nekognityvinių asmenybės savybių vaidmuo akivaizdžiai nepakankamai ịvertintas, šiuolaikiniai mokyklinès ir universitetinès socializacijos modeliai neprisideda prie sèkmingo nekognityvinių asmenybès savybių formavimo.

Straipsnio pagrindas - empirinis tyrimas: apklausti 929 bendrojo ugdymo mokyklų vadovai; tai sudaro 93 proc. tikslinès populiacijos. Pateikiami atsakymai ị atviro tipo klausimą: „Kokių mokytojų laukia šiuolaikinè mokykla, kokių asmeninių savybių turètų turèti pedagoginių fakultetų ir universitetų absolventai?“. Duomenys apdoroti, taikant kiekybinę turinio analizę. Konceptualaus tyrimo pagrindą sudaro sąvokų „Job Description“ ir „Job Specification“ bei „nekognityvinès asmenybès savybès“ semantika.

Apklausos duomenys rodo, kad mokyklų vadovai linkę pripažinti nekognityvinių savybių svarbą mokytojo profesinei sėkmei. Straipsnyje taip pat bandoma: a) atskleisti teorinio koncepto „nekognityvinès asmenybès savybès“ euristines galimybes ir svarbą būsimiems tyrimams; b) atkreipti dèmesị ị kai kuriuos plačiai vartojamų „kompetencijos“ ir „emocinès inteligencijos“ EQ sąvokų epistemologinius ribotumus.

Esminiai žodžiai: nekognityvinès asmenybès savybès, mokyklinè ir universitetinè socializacija, mokyklu vadovu apklausa, mokytojų rengimas, kognityvinis redukcionizmas. 